\title{
Proposed Models for Genetic Counseling: Which Quality Indicators by Donabedian's Model are more Feasible?
}

\author{
Marija M. Lević́ ${ }^{1}$ Dušanka M. Krajnović2,3, Valentina D. Marinković \\ ${ }^{1}$ University of Belgrade, Faculty of Pharmacy, Department of Social Pharmacy and Pharmaceutical Legislation, \\ PhD student, Belgrade, Serbia \\ ${ }^{2}$ University of Belgrade, Faculty of Pharmacy, Department of Social Pharmacy and Pharmaceutical Legislation, \\ Belgrade, Serbia \\ ${ }^{3}$ University of Belgrade Center for the Study of Bioethics, Belgrade, Serbia
}

\begin{abstract}
SUMMARY
Genetic counselling is a complex process that helps people to understand and adopt medical, psychological and genetic aspects of the disease and enable them to make an appropriate decision.

In this framework, we revisited all the existing models for decision-making and suggested their use in the process of genetic counselling, which may lead to more equitable and more favourable outcomes. Also, Donabedian's (Structure-Process-Outcome) model for the development of key performance indicators was applied to assess the quality in the process of genetic counselling.

Quality indicators at SPO model in the process of genetic counselling were proposed. The social, economic and humanistic outcomes have also been identified.

All defined quality indicators together represent a framework for monitoring, evaluation and continuous improvement of the process of genetic counselling. Although the new medical services of genetic counselling tend to be developed as a powerful multidisciplinary field, the implementation of quality management model will certainly help the development of collaborative practice.
\end{abstract}

Key words: genetic counselling, models of decision-making, Donabedian's model, quality

Corresponding author:

Dušanka Krajnović

e-mail: dusica.krajnovic@pharmacy.bg.ac.rs 


\section{INTRODUCTION}

\section{Genetic counselling}

Genetic counselling (GC) is a complex process of advising patients or relatives about the risk, consequences and the nature of inherited disorders. It is assosiated with different genetic researches, and involves pre-test counselling as well as post-test counselling to enable the individuals to face the research results and to take appropriate decisions with the right information.

Genetic testing before the start of drug therapy in order to predict their likely response is crucial in achieving the desired effect. Genetic counselling aims to encourage people to decide on testing, to assist in a common understanding of genetic diseases, and to provide psychological support after testing. It has a role before, during and after the test (1). More professionals should be involved due to the complexity of genetic counselling. Associated engagement of pharmacists and genetic counsellors can assist physicians in understanding and interpreting the results of pharmacogenetic testing. Pharmacists can use their knowledge from pharmacokinetics and pharmacodynamics and help physicians to choose the appropriate drug or proper dosage, and to avoid possible adverse reactions. They are also included in patients' education, recommending testing and reporting on patients' test results. However, their knowledge of genetics is not enough, and therefore genetic counsellors must be involved in dealing with specific issues for genetic testing.

Delivery of pharmacogenetic services by pharmacists or genetic counsellors can be conducted in person, electronically (e.g. by providing recommendations to physicians with checking patients' laboratory analyses or electronic health records), or by phone (providing advice to patients or physicians) (2).

It is important to achieve and maintain high quality in genetic counseling. It largely depends on the health professionals who participate in counseling. If doctors in primary health care or surgeons are involved, it would be necessary to be qualified in the field of genetics. Quality can be increased by improving the training of genetics for medical students and physicians with providing information about the existence of genetic counseling and potential problems. Genetic counsellors should have some sort of accreditation, which includes appropriate training and exams (3). For pharmacists, the introduction of pharmacogenetics into the curriculum is recommended, as well as providing access to educational programs in pharmacogenetics that will help them to make appropriate use of laboratory diagnostics (2).

Increasing demand for genetic counseling in recent years leads to the following results: 1) search for quality genetic counselling; 2) growing awareness that our knowledge of the genetic counseling services is poor (3).

\section{Models of decision-making in genetic counseling}

The question that is often asked is whether the genetic counseling can be seen as part of regular healthcare interaction or as a separate discipline? The research carried out on this subject has shown similarities between communication in the process of genetic counseling and other healthcare interactions, challenging the claim that is regarded as a separate service due to the large presence of bioethics in this field.

A patient-centred approach is often implemented in the interactions of healthcare and even genetic counseling is not an exception. Family involvement was shown as a significant help to the patient.

Communication and exchange of information are very important in establishing a good relationship. Difficulties in genetic counseling as well as other interactions are the lack of alignment between what the patient expects to hear and what the healthcare professional carries out.

Shared decision-making is an integral part of all healthcare services, and it is the preferred model for both genetic and non-genetic healthcare professionals, as well as providing emotional support.

Geneticists have more specialized knowledge of this field than other non-genetic professionals. Association with non-genetic professionals can significantly contribute to the discipline of genetic counselling, because the introduction of similar concepts and methodologies can help genetic counsellors to expand various possibilities of information exchange with other professionals involved in the 
testing and improvement of medical communications (4).

There are several models of decision-making in health care. Among them are observed differences in the objectives of interaction between counsellors and patients, the duties and responsibilities of counsellors, the role of patient and the concept of patient autonomy. We shall evaluate these models and recommend their use in the process of genetic counseling.

The first is paternalistic model, where the dominant role of clinicians who can make the best decision for a patient is presented. This model is described as a unilateral decision unrelated to the patient's wishes and values. However, sometimes it is necessary for physicians to make a decision that is in the best interest of their patient without his prior consultation. As has been known since the time of Hippocrates, a doctor always has a goal and that is the benefit of his patient (5).

The second model is known as "autonomous" or "patient-centred". In this model, a clinician communicates to a patient available options and relevant medical information, but the patient select their ed $c$ $x$ own treatment. Patient-centred care is defined as: "The experience of transparency (to the extent that the informed, individual patient desires it), individualization, recognition, respect, dignity, and choice in all matters, without exception, related to one's person, circumstances, and relationships in healthcare". Knowledge is a transfer from a patient to a provider (6).

The following is shared decision-making (SDM), which is a collaborative process where a clinician/counsellor and a patient communicate taking into account the most relevant evidence in making appropriate decisions. This process aims to increase the involvement of all participants in the chain of decision-making at all levels (7).

Finally, there is collaborative decision-making (CDM) in which both sides "work together, especially in a joint intellectual effort". While counsellors know more and have experience with medical issues, patients have their own and life experiences. Patients also may possess medical knowledge which should be taken into account (8).

\section{Ethical principles}

Genetic counselling raises special ethical issues related to confidentiality and privacy pro- tection. Information about the individual, family history, carrier status, risk of genetic disease can be stigmatising and hence needs to be kept confidential. Most of the time, the patient is concerned about the future reproductive or personal health risks. The counsellor has to make an assessment by obtaining family history and by analysing the pedigree chart to provide information regarding the treatment options, preventive strategies, including reproductive options and the financial and social implications.

Ethical issues to take into consideration when providing GC:

a) respect for patient autonomy;

b) respect for patient confidentiality;

c) respect for patient privacy;

d) right to information and the right to make his/her own decisions;

e) non-maleficence, which is defined as one's "duty to minimize or prevent the infliction of harm on individuals and families";

f) beneficence, or taking action to help others and prevent harm, both physical and mental;

g) justice, which requires that services must be distributed fairly to those in need;

h) veracity, the duty to disclose information or to be truthful.

\section{Donabedian's model as a framework of quality in health care}

Avedis Donabedian introduced the basic concept of quality health care. This model describes three fundamental parts of health care and their mutual relationship.

Firstly, structure represents the methods of providing health care that refers to the appropriate facilities and equipment, adequate number of qualified healthcare professionals and their diversity. Also, it is referred to organizational characteristics such as the organization of personnel, training, the methods of payment of health care, as well as administrative structure and programs. Structure can sometimes be a major determinant of the quality assessment of health system. Some features of the structure can be easily monitored. They are more stable and simpler for documenting. But, on the other hand, numerous variations in the structure are less related to variations in outcomes, because in practice it is usually not a good setting of the relationship between structure and process and structure and outcome. 
Secondly, the process means the activities in the provision of health care that includes: health promotion, disease prevention, treatment, rehabilitation and patient education. It is very important to apply the appropriate values and standards to be used in the assessment. Monitoring process is facilitated by current events and easy collection of patient data through observation, examination or from medical records. Although the quality of providing health care is often identified with the quality of health care, it is necessary also to take into account the established connection between process and outcome.

Finally, the third determinant outcome describes a change in a person's health (desired or not), that can be connected with health care. In the evaluation of patient attitudes and satisfaction, it is sometimes difficult to measure outcomes as they are not expressed quickly. It is often difficult to make a connection between the previous health care and resulting outcomes. Donabedian said that measuring the quality of health care services is not accurate, also it is not complete, and it should have flexibility in interpreting the outcome, which cannot be considered separately from the structures and processes.

It is important to determine the impact between these major components: the direct influence of structure on a process and the process on the result. Also, outcomes provide feedback to the structure and process to define the changes that are needed to be applied.

Donabedian's model has undergone various changes in recent years, which makes it specific for the implementation of new services in modern health care. However, the base has remained the same (9).

\section{AIMS}

The aims of this paper are: (a) reviewing the existing models of decision-making at health care services that could be applied for the counselling phase of genetic counselling service, (b) identification for QM for the counselling phase in GCS (c) the development of quality management indicators for proposed genetic counselling models.

\section{METHOD}

We used manual documentation analysis to find models of decision-making in health care and quality indicators by Donabedian's model with the possibility of adapting the application in the process of genetic counselling. Given that the interest of research was predominantly in the literal wording and terminology, manual method is shown in Table 1.

The process of analysis included several steps. The first step was the selection of documents including a comparison with other framework. In this step, we considered all the existing models of decisionmaking and documents on the topic of Donabedian's model. In the next step we dealt with the reading and interpretation of works in order to determine the purpose and objectives and the understanding of the content. Then we considered the terminology characteristic of the objectives previously set and the generalization of the terms by searching key words or phrases. In the last step, we evaluated models and recommended their use in the genetic counselling. Also, we proposed quality indicators at the structure-process-outcome model in the process of genetic counselling.

Table 1. The stages with considerations of manual documentation analysis

\begin{tabular}{l|c|c}
\hline \multicolumn{2}{|c|}{ Manual documentation analysis } & Considerations \\
\hline Stage 1 & $\begin{array}{c}\text { The selection of documents and } \\
\text { comparison with other frameworks }\end{array}$ & $\begin{array}{c}\text { The decision-making models in health care and } \\
\text { quality indicators by Donabedian`s model }\end{array}$ \\
\hline Stage 2 & Reading and "interpretation" & The purpose and objectives of the documents \\
\hline Stage 3 & Searching by key words or phrases & $\begin{array}{c}\text { The terminology characteristic of the set objectives } \\
\text { and generalizability of terms }\end{array}$ \\
\hline Stage 4 & Recording and reconciliation of findings & $\begin{array}{c}\text { Proposing the application of models and quality } \\
\text { indicators in the process of genetic counseling }\end{array}$ \\
\hline \hline
\end{tabular}




\section{RESULTS}

We collected four models from the literature concerning the decision-making in health care settings as presented in Table 2 . The first analyzed model was paternalistic model, where the counsellor has the parental role and he decides what is the best for the patient. The counsellor has obligations to use their knowledge in identifying the medical condition of the patient and to find a suitable test that would allow the diagnosis, drug selection and dosing, providing selected information to encourage patients to make a decision about testing with the goal of pro- viding the patients' well-being. In an extreme situation, the counsellor may inform the patient about the beginning of the process without the patient's response. Also, the counsellor has a duty to put the interest of the patient above his personal, and to seek the assistance of another professional if they do not possess the required appropriate knowledge.

The concept of patient autonomy in this model refers to the assent of the patient at the time, or later when the counsellor determines what is the best for the patient.

Table 2. The models of decision-making in health care and GC feasibility [adapted from reference 5].

\begin{tabular}{c|l|l|c|c|c}
\hline \hline Model & Provider & Patient & Knowledge flow & Objective & $\begin{array}{c}\text { Feasibility } \\
\text { to GC }\end{array}$ \\
\hline Paternalistic & Directive & Passive & $\begin{array}{c}\text { One-way knowledge } \\
\text { transfer: provider to patient }\end{array}$ & Patient compliance & Low \\
\hline Autonomous & Receptive & Directive & $\begin{array}{c}\text { One-way knowledge } \\
\text { transfer: patient to provider }\end{array}$ & Provider compliance & Medium \\
\hline $\begin{array}{c}\text { Shared decision- } \\
\text { making }\end{array}$ & Informative & Informative & $\begin{array}{c}\text { Two-way knowledge } \\
\text { exchange }\end{array}$ & $\begin{array}{c}\text { Equity in the } \\
\text { decision-making } \\
\text { process }\end{array}$ & High \\
\hline $\begin{array}{c}\text { Collaborative } \\
\text { decision-making }\end{array}$ & Supportive & Proactive & $\begin{array}{c}\text { Knowledge builds through } \\
\text { shared learning }\end{array}$ & Optimal action & High \\
\hline \hline
\end{tabular}

It is well-known that the paternalistic model is suited to emergency situations where the waiting time for the patient consent to participate in testing may adversely affect his health. Probably, for counsellors and patients, this will not be an ideal model for counsellor-patient relationship.

In patient-centred model, the information is directed from the patient to the counsellor. Of course, counsellor must inform the patient about their medical condition and disease, the nature of genetic testing, the benefits and risks of the same and they must resolve any ambiguity or the lack of knowledge.

In this model, the patient's values are wellknown and defined. The values of the counsellors are not involved, due to their role is understand the patient's values.

Counsellors as tehnical experts have an obligation to provide truthful information, to maintain competence in their area, and certainly to consult with other health care professionals in case of inade- quate knowledge. The concept of patient autonomy is based on the fact that patient controls the whole medical decision-making.

The following model included in the review is shared decision-making, where great importance is emphasized for both sides to framework SDM application in the process of genetic counselling. With respect to the focus of the patient's health, there are justifiable reasons for including genetic counsellors in this process by providing evidence that will be of direct medical benefit to the patient, with respecting his or her ultimate autonomy.

This framework would allow geneticists to communicate complex information on risks and uncertainties to patients. It can also help the counsellor to provide clinical recommendations that are significant by giving theirexpert opinion. SDM can be helpful in diagnostic pathways when patients are faced with discomfort, anxiety, pain and other conditions.

Another important aspect in this process is the 
implication of genetic information to other family members. This is very important for them to be able to organize their lives, to plan reproduction and to control the early signs of complications that can be cured if detected in time. Counsellors should support those patients who wish to transfer genetic information that can be useful, even by giving them a bit of persuading to do.

The decision-making process in this comprehensive discipline moved to a collaborative mode. The collaborative decision-making combines the talents and experiences of all individuals. While coun- sellors know more and have experience with medical issues, patients have their own and life experiences. Patients also may possess medical knowledge which should be taken into account.

\section{What is the philosophy of CDM?}

- Embraces partnership;

- Combines the talents and the experience of ALL individuals and organisations;

- Shares values and preferences;

- Encourages sharing information and management (8).

Figure 1. Quality Management in CDM in the Genetic Counseling Services

\section{Genetic Counseling Path of Workflow}

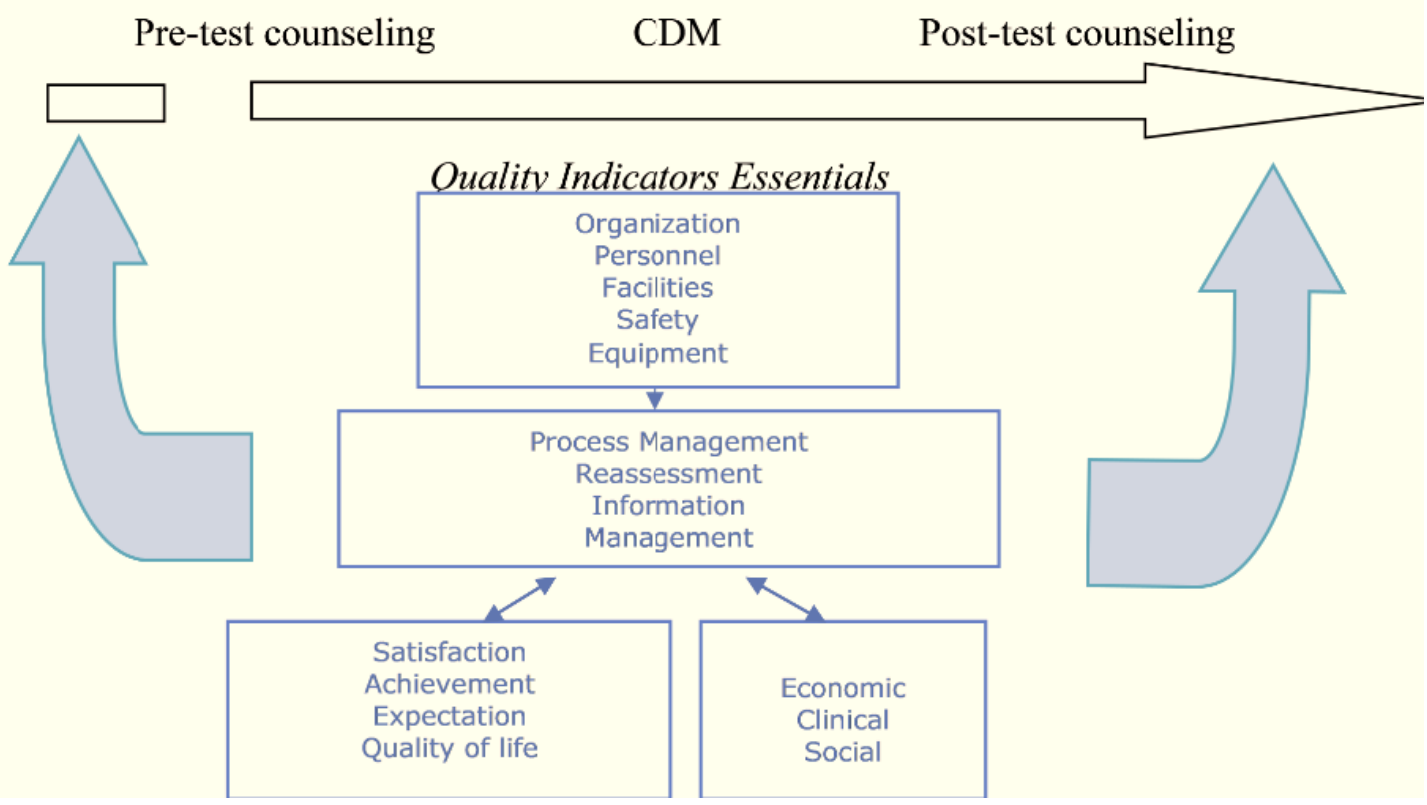

The role of the counsellor is to inform the patient about the reasons for testing, and what to expect regarding the process of pharmacogenetic testing. Counsellor and patient together formulate decisions on treatment.

This framework allows the counsellor to shape medical issues and to ensure their participation in the health management process of patients with clearly defined and emphasized responsibilities and boundaries. The patients must have an abandoned place for reconsideration of their decision.

Collaborative decision-making model unlike other models focuses on the highest priorities re- garding health problems. The implementation of this model will allow patient to solve medical problems in the context of a much richer and more complex life (adapted from 8 and 5). Quality Management $\mathrm{CDM}$ in the Genetic Counseling Services is presented in Figure 1.

\section{Quality indicators in genetic counseling}

Donabedian's SPO model was a conceptual point for the research and development of key performance indicators for assessing the quality of. service in genetic counselling. In Table 3, theclassifi- 
Table 3. The classification of key performance indicators for Genetic Counseling Services (GCS)

\begin{tabular}{l|c|c|c|c|c}
\hline \hline S & Structure indicators & $\mathbf{P}$ & Process indicators & O & $\begin{array}{c}\text { Outcome } \\
\text { indicators }\end{array}$ \\
\hline S.1 & $\begin{array}{c}\text { Information, availability and transparency for } \\
\text { consumers on GCS }\end{array}$ & $\mathbf{P . 1}$ & $\begin{array}{c}\text { Standard operative procedures } \\
\text { for the GCS }\end{array}$ & $\mathbf{O . 1}$ & $\begin{array}{c}\text { Psychosocial } \\
\text { support }\end{array}$ \\
\hline S.2 & $\begin{array}{c}\text { Human Resources (the number of counsellors } \\
\text { and the expertise of counsellors per GCS) }\end{array}$ & $\mathbf{P . 2}$ & $\begin{array}{c}\text { The number of counseling per } \\
\text { patient }\end{array}$ & $\mathbf{O . 2}$ & $\begin{array}{c}\text { Cost-benefit } \\
\text { analysis }\end{array}$ \\
\hline S.3 & Equipment and facilities & $\mathbf{P . 3}$ & $\begin{array}{c}\text { The number of counseling } \\
\text { provided per GCS }\end{array}$ & O.3 & $\begin{array}{c}\text { Patient } \\
\text { expectations }\end{array}$ \\
\hline S.4 & The education of GCS members & $\mathbf{P . 4}$ & $\begin{array}{c}\text { The number of positive } \\
\text { decisions made per GCS }\end{array}$ & $\mathbf{O . 4}$ & $\begin{array}{c}\text { Patient } \\
\text { satisfaction }\end{array}$ \\
\hline S.5 & Payment for GCS & $\mathbf{P . 5}$ & $\begin{array}{c}\text { The number of positive } \\
\text { decisions made per patient }\end{array}$ & $\mathbf{O . 5}$ & $\begin{array}{c}\text { The quality of } \\
\text { life }\end{array}$ \\
\hline \hline
\end{tabular}

cation of key performance indicators for monitoring, assessment and continuous improve-ment in genetic counselling were identified.

\section{Indicators of structure}

An enormous effort must be invested in ensuring the availability of genetic testing, following many countries of Europe and the United States and advocating for their commercial use, in order to select the appropriate drug specific for each patient, to shorten the time of treatment and to avoid patient suffering as well as his family and to reduce unnecessary costs.

The existence of a large number of various health professionals is essential for providing genetic counseling. It involves mutual cooperation of general practitioners, medical geneticists, genetic nurses, pharmacists and genetic counsellors. The popular survey of health care professionals in terms of their priorities in the selection of appropriate health care professionals for providing genetic counselling have shown that primary care has the primary role. In terms of the selection of the required test, they gave an advantage to medical genetics. Still in the stage of making attempts, they had a great interest in paying attention to the proposed partnership between genetic counsellors and pharmacists, and their benefits to all (10).

These test results depend heavily on the expertise of health care professionals. With this re- gard, it is necessary to provide support for specific genetic courses and trainings and to enable them to access the electronic sources of information. A cooperation of European countries as well as an adaptation of curricula are needed (11).

The knowledge and understanding of the patient's need for genetic counseling and genetic testing is still at a low level. Patient education is crucial to realize that they have enough knowledge about the disease, then a potential risk for themselves and their families, and thus enable the available support, disease prevention and treatment needed.

When asked a question about how they would like to be informed, whether through a computer program that contains all necessary pieces of information, or by genetic counselors, the opinions were divided. In terms of genetic counselors, they emphasized the advantage of personal discussionlistening caution and compassion with their emotional problems, considering options, saying what is important to know and supporting them. With computer programs, patients see the benefits of learning tailored to their pace, better use of time and avoiding embarrassment (12).

Payment for genetic counseling service has become a major problem that has seen strong growth in recent years. Proposal is to subsidize the cost by state as the number of health services, since ex-post payment cannot cover many procedures (3). 


\section{Indicators of process}

Our reputed process of genetic counselling would include the following steps:

1) Observing family history that covers all medical problems;

2) Analyzing a family history of genetic and/or other birth defects;

3) Assessing the risk of occurrence or recurrence genetic abnormalities in the family;

4) Discussing its nature with emphasis on the inheritance factor;

5) Pointing out the available options to reduce risk, including genetic testing;

6) Discussing the benefits and risks of each possible option with paying due attention to the patient's understanding;

7) Providing assistance in choosing the appropriate decisions for the patient and his family;

8) Providing supportive counselling when it is needed;

9) Assisting in carrying out testing;

10) Documenting the process of counselling (adapted from the 13).

\section{Indicators of outcomes}

Genetic counsellors provide psychosocial support, show concern, empowerment and decision support, primarily in terms of patient benefits. Patients see it as encouraging, because by transferring experiences to counsellors, this enables them to cope with their problems. They stress the importance of long-term support, which are held by telephone or by other means, and the availability of genetic counsellors whenever is needed.

In the process of genetic counseling, patients expect professionalism and the expertise of counsellors. Patients emphasized the importance of providing information and transferring knowledge.

Consideration of the outcome of genetic counselling leads to the conclusion that facilitates communication within family. Counsellors suggest the necessity of a family member to attend counseling in order to comprehend the family history as well as to show greater understanding and to be involved in the patient's thinking. They believe that it really means a lot to the patient (14).

Given that this service is different from many medical services, it cannot point to a direct benefit to health. Measures that assess the health status and the quality of life are rarely used in genetic counseling, for example, they are used in cancer genetics. In this area, concern is significantly correlated with an increased anxiety and stress, and interferes with the usual function and health, that is especially pronounced in case of positive family history (15).

The ultimate outcome of the service provided, which is also of utmost importance, is patient's satisfaction. If patient's expectations are met, the goal is achieved.

\section{Economic, clinical and humanistic outcomes (ECHO model)}

The Echo model represents the value of pharmaceutical services that combines traditional clinical outcomes with contemporary outcomes relating to economic efficiency and quality. It views the service as pooling of their economic, social and humanistic outcomes. Safety and efficacy have not been more than only the essentials, but the importance is given to the effect on the total health resource use, costs, and the quality of life. The Echo model should help the providers of health services in the planning, implementation and evaluation of its services from a wider point of view (16).

Economic outcomes represent total costs (medical, non-medical and indirect) associated with treatment alternatives that are in balance with social and humanistic outcomes. The purpose of introducing the concept of pharmacogenomics was to identify a specific drug that can be safe, efficient and cost-effective for a patient. In compliance with limited healthcare budgets, it is necessary to consider that the best health interventions are applicable, useful for the patient and cost justified. Pharmacogenomic services showed a higher value in terms of benefits and costs compared to current interventions (17). Two facts should be noted: 1 . the costs of using pharmacogenetic tests are more expensive than the cost of the test; 2 . they are related to the impacts on other health interventions such as managing drug side effects, blood tests, and others. The people responsible for the health budget will decide on the type of cost in proportion to the money they have. Then, the value associated with the payment of genetic counsellors and other health professionals involved was analyzed. Introduction of tests is intended to reduce side effects and to improve better adherence by patients and consequently, a better quality of life. It is not easy for decision 
makers to introduce pharmacogenetic testing due to a lot of things that must be taken into consideration. (18). The recommendation is to apply the costeffectiveness analysis in order to estimate the technical efficiency of an intervention. The costeffectiveness analysis is one of the most commonly used type of economic evaluation that compares similar therapeutic interventions in terms of their effects on the basis of the achieved cost per unit. This analysis in pharmacogenomics involves an assessment of factors such as genetic testing, disease stage and treatment. Genetic testing would be cost effective in the following cases: 1 . when a cheaper, alternative test for diagnosis is not available, the use of genetic tests that are highly sensitive and specific is presumed; 2. when it comes to diseases in which mortality is expected if left untreated; 3 . when polymorphism prevails in the population, and 4 . when a treatment involves significant costs or results that can be avoided by the genotype-individualized therapy. Pharmacogenomics is appropriate to be applied for diseases that require medication with narrow therapeutic range, with large inter-individual response, in which alternative methods of monitoring and treatment do not exist or are not available (19). It is necessary to understand the present situation in order to improve the cost analysis model in the future. Better methodological challenges are expected. Clinicians and people who make decisions regarding the allocation of resources for pharmacogenetic tests should have enough robust information on the benefits and costs of patients. Therefore, it is necessary to include genetic counsellors who will give the right and necessary information which will help the patient in making decisions regarding genetic testing and thus reduce unnecessary costs. The introduction of genetic counseling is a key step in pharmacogenetics.

Clinical outcomes are medical events that occur as a result of disease or treatment. With emphasis on the benefit of pharmacogenetic tests, it is the potential reduction of adverse effects compared to traditional methods. Some adverse reactions, including serious ones such as morbidity and mortality caused by the genetic variation, can now be prevented. A modified dose or the dosage of the drug in patients who have a reduced capacity to metabolize due to genetic variability, will help in avoiding the adverse metabolic pathways. In the case of diseases where it is possible to take certain measures to protect patients from the harmful effects of the mutated gene, it is essential that a genetic counsellor monitors a relative of this person. In children with metabolic errors such as the genetic types of cretinism, phenylketonuria and galactosemia, it has previously been advised that treatment starts as soon as possible based on genotyping. Counselling is also necessary in case of a deficiency of G6PD, malignant hyperthermia, as well as in the deficiency of pseudo cholinesterase and other diseases, where the mutant individual must be protected against specific agents. Patients with hypertriglyceridemia and hypercholesterolemia should be warned about protective measures related to the cardiovascular system, while patients with congenital A1 - antitrypsin deficiency should be advised not to smoke. In these diseases, the significance of monitoring relatives is performed in order to prevent adverse clinical outcomes (3).

Humanistic outcomes represent the functional status or the quality of life. The importance of including genetic counsellors, with respect to their psychological impact on the genetic information received by patients, is emphasized. They are reflected in visible changes in the patient's satisfaction with understandable information, the ability to work, social reintegration, avoiding undue stress and, above all, patients'psychological well-being. These outcomes help in the evaluation process of genetic counseling, if they are appropriate. Meeting the needs and priorities of patients are of vital importance for genetic counsellors. Patients need to talk about their needs in meetings with a counsellor so as their expectations could be met. The patient's attitudes and beliefs should be recognized in their speech, as well as feelings, whether they are feelings of guilt, stress, crying, loss of will and worthlessness. It is up to genetic counsellors to be good psychologists and it is one of the requirements they must meet. Patients will not be able to define their expectations if they do not understand the nature of counseling, or do not have the opportunity to consider the benefits of counseling. It has been proven that when they met their expectations regarding the provision of appropriate advice and security, the patients' concern and anxiety were avoided. If patients are not sure that they have had a consultation process, they would not be able to assess whether it was necessary or not. Objectives and their explanations must be clearly indicated by the counsellor. The process that will indicate whether the patient understands the information 
received and whether communication was understandable is necessary to exist. When these criteria are met, patients will be able to play the role of interactive participants in the counseling process (20).

\section{CONCLUSIONS}

Genetic counseling is a relatively new medical service with a tendency to be widely applied. This audit has demonstrated that the existing models of decision-making are applicable for genetic counselling services. It is shown that better outcomes are achieved by moving towards a collaborative model that requires certain changes in thinking and acting as counsellors and patients. Both parties must acknowledge that learning from each other and building shared knowledge in order to achieve an appropriate level of relations are indispensable steps. We have also introduced the quality indicators of Donabedian's model in the process of genetic counselling. Quality indicators are an important instrument for measuring quality. Their validation is needed to enable the feasibility in clinical practice and to lead to improved outcomes. The implication of science would lead to meaningful quality assurance in the field of genetic counselling, that will certainly be realized in the future.

\section{Acknowledgement}

This article is based upon the work of Dušanka Krajnović under the COST Action IS1303 "Citizen's Health through Public-Private Initiatives: Public Health, Market and Ethical Perspectives", supported by COST (European Cooperation in Science and Technology http://www.cost.eu). The authors have no competing interests.

At the time of research, the work of DK was partially supported by the framework of a project of Ministry of Education, Science and Technological Development of the Republic of Serbia (project No. 41004). She is now receiving grant from the Ministry of Education, Science and Technological Development of the Republic of Serbia MPNTR: 45103-68/2020-14/200161.

\section{References}

1. Ellingrod VL, Moline J. Incorporating Pharmacogenomics into Practice. J Pharm Prac 2007; 20: 277-82. https://doi.org/10.1177/0897190007304820

2. Mills R., Haga SB. The Clinical Delivery of Pharmacogenetic Testing Services: A Proposed Partnership between Genetic Counsellors and Pharmacist. Pharmacogenomics 2013; 14(8): 957-68. https://doi.org/10.2217/pgs.13.76

3. Fraser FC. Genetic counseling. Am J Hum Genet 1974; 26(5): 636-61.
4. Smets E, van Zwieten M, Michie S. Comparing genetic counseling with non-genetic health care interactions: Two of a kind? Patient Educ Couns 2007; 68: 225-34.

https://doi.org/10.1016/j.pec.2007.05.015

5. O'Grady L, Jadad A. Shifting from Shared to Collaborative Decision Making: A Change in Thinking and Doing. J Particip Med 2010; 2, e13.

6. Emanuel EJ, Emanuel LL. Four models of the physician-patient relationship. JAMA 1992; 267: 2221-6. 
https://doi.org/10.1001/jama.1992.03480160079038

7. Elwyn G, Gray J, Clarke A. Shared decision making and non-directiveness in genetic counseling. Med Genet 2000; 37: 135-8.

https://doi.org/10.1136/jmg.37.2.135

8. Tisdall A CANSO, Collaborative Decision Making. Advanced ATM Techniques Symposium and Workshops, 2013

9. Donabedian, A. "Evaluating the quality of medical care" The Milbank memorial fund quarterly 1966; 44(3): 166-206.

https://doi.org/10.2307/3348969

10. Haga SB, Burke W, Ginsburg GS, Mills R. Primary care physicians' knowledge of and experience with pharmacogenetic testing. Clin Genet 2012; 82(4): 388-94.

https://doi.org/10.1111/j.1399-0004.2012.01908.x

11. Skirton H, Lewis C, Kent A, Coviello DA. Genetic education and the challenge of genomic medicine: development of core competences to support preparation of health professionals in Europe. Eur J Hum Genet 2010; 18(9): 972-7.

https://doi.org/10.1038/ejhg.2010.64

12. Green MJ, Mclnemey AM, Biesecker BB, Fost N. Education about genetic testing for breast cancer susceptibility: Patient preferences for a computer program or genetic counselor. A J Med Genet 2001; 103(1): 24-31.

https://doi.org/10.1002/ajmg.1501

13. Beth B. Genetic Consultation/Counseling: The Process. Genzyme Genetics. 1996.
14. Bernhardt BA, Biesecker BB, Mastromarino CL. Goals, Benefits, and Outcomes of Genetic Counseling: Client and Genetic Counselor Assessment. Am J Med Genet 2000; 94(3):189-97. https://doi.org/10.1002/10968628(20000918)94:3<189::AID-AJMG3>3.0.CO;2-E

15. Payne K, Nicholls S, Mc Allister M, et al. Outcome Measurement in Clinical Genetics Services: A Systematic Review of Validated Measures. Value in Health 2008; 11(3): 497-508. https://doi.org/10.1111/j.1524-4733.2007.00259.x

16. Kozma C, Reeder C, Schulz R. Economic, clinical, and humanistic outcomes: a planning model for pharmacoeconomic research. Clin Ther 1993; 15(6):1121-32.

17. Payne K, Shabaruddin FH. Cost-effectiveness analysis in pharmacogenomics. Fut Med 2010; 11(5): 643-6.

https://doi.org/10.2217/pgs.10.45

18. Payne K. Towards an economic evidence base for pharmacogenetics: consideration of outcomes is key. Fut Med 2008; 9(1): 1-4.

https://doi.org/10.2217/14622416.9.1.1

19. Flowers CR, Veenstra D. The role of cost-

effectiveness analysis in the era of

pharmacogenomics. Pharmacoeconomics 2004; 22(8): 481-93.

https://doi.org/10.2165/00019053-200422080-00001

20. Biesecker BB, Peters KF. Process studies in genetic counseling: Peering into the black box. Am J Med Genet 2001; 106(3):191-8.

https://doi.org/10.1002/ajmg.10004 


\title{
Predloženi modeli genetskog savetovanja: koji indikatori kvaliteta Donabedijanovog modela su primenljiviji?
}

\author{
Marija M. Lević1, Dušanka M. Krajnović2,3, Valentina D. Marinković \\ ${ }^{1}$ Univerzitet u Beogradu, Farmaceutski fakultet, Katedra za socijalnu farmaciju i istraživanje farmaceutske prakse, \\ student na doktorskim studijama, Beograd, Srbija \\ ${ }^{2}$ Univerzitet u Beogradu, Farmaceutski fakultet, Katedra za socijalnu farmaciju i istraživanje farmaceutske prakse, \\ Beograd, Srbija \\ ${ }^{3}$ Univerzitet u Beogradu, Centar za bioetičke studije, Beograd, Srbija
}

\section{SAŽETAK}

Genetsko savetovanje je složen proces koji pomaže ljudima da razumeju i prihvate medicinske, psihološke i genetske aspekte bolesti, kao i da donesu odgovarajuću odluku u vezi sa njima. $U$ ovom radu, revidirani su svi postojeći modeli za donošenje odluka i predložena je njihova upotreba u procesu genetskog savetovanja, što može da dovede do pravičnijih i povoljnijih ishoda. Za procenu kvaliteta u procesu genetskog savetovanja primenjen je Donabedijanov model (Struktura-proces-ishod), za razvoj ključnih pokazatelja performansi. Predloženi su pokazatelji kvaliteta na "Struktura-proces-ishod" modelu u procesu genetskog savetovanja. Takođe, utvrđeni su socijalni, ekonomski i humanistički ishodi. Svi definisani indikatori kvaliteta zajedno predstavljaju okvir za praćenje, procenu i kontinuirano unapređenje procesa genetskog savetovanja. Iako se nova medicinska usluga genetskog savetovanja razvija, kao snažno multidisciplinarno polje, primena modela upravljanja kvalitetom sigurno će doprineti razvoju kolaborativne prakse.

Ključne reči: genetsko savetovanje, modeli donošenja odluke, Donabedijanov model, kvalitet 